and leucine $\beta 88$. Thus, for example, the $D$ isomeric forms of aromatic amino acids are as active as the $\mathrm{L}$ isomers ${ }^{10}$. This supports the hypothesis that the inhibition of polymerization by these compounds is brought about by competition between the water polyhedra filled with the small hydrophobic molecules with those attached to the protein, rather than a direct interaction between the hydrophobic residues and the protein which should be stereospecific. This picture would also explain why attempts to increase the effectiveness of hydrophobic antisickling agents by structural modification have met with relatively little success.

1. Schechter, A. N. Hemoglobin 4, 335 (1980).

2. Development of Therapeutic Agents for Sickle Cell Disease INSERM Symp. (eds Beuzard, Y., Hercules, J. \& Rosa, J.) (Elsevier, Amsterdam, 1979).

3. Stillinger, F. H. Science 209, 451 (1980)
4. Wishner, B. C., Ward, K. B., Lattman, E. E.\& Love, W. E. J. molec. Biol. 98, 179 (1975).

S. Elbaum, D., Nagel, R. L., Bookchin, R. M.\& Herskovits, T. T. Proc. natn. Acad. Sci. U.S.A. 71, 4718 (1974).

6. Ross, P. D. \& Subramanian, S. Biochem. biophys. Res. Commun. 77, 1217 (1977).

7. Votano, J. R., Gorecki, M. \& Rich, A. Science 196, 1216 (1977).

8. Kubota, S. \& Yang, J. T. Proc. natn. Acad. Sci. U.S.A. 74, 5431 (1977)

9. Behe, M. J. \& Englander, S. W. Biochemistry 18, 4196 (1979).

10. Noguchi, C. T. \& Schechter, A. N. Biochemistry 17, 5455 (1978).

\title{
Fifty years of Slough's ionosphere
}

\section{from Henry Rishbeth}

ON 11 January 1981 the 'noon run' of the Slough ionosonde marked with due ceremony the fiftieth anniversary of routine ionospheric sounding. An ionosonde is a kind of swept-frequency radar and radar developed from the experimental studies of the ionosphere that were conducted at Slough and elsewhere in the twenties and thirties. This work followed from the basic experiments of 1924-25 in Britain (E. V. Appleton and M. A. F. Barnett Nature 115, 333; 1925) and in the US (G. Breit and M. A. Tuve Nature 116, 357; 1925) that conclusively proved the existence of radio-reflecting layers in the upper atmosphere. It was Watson-Watt at the Radio Research Station (RRS), Slough (now the SRC Appleton Laboratory) who coined in 1926 the term 'ionosphere' (G. W. Gardiner Nature 224, 1096; 1969). Years later, the output of analysis and interpretation based on Slough data gave rise to the unofficial definition of the ionosphere as 'the part of the atmosphere vertically above Slough'.

To promote scientific understanding of the ionosphere and to meet the growing needs of radio communications, systematic data were needed. RRS publications contain some $h^{\prime}-f$ data on apparent reflection heights $\left(h^{\prime}\right)$ at different radio frequencies $(f)$ obtained in 1930. However, the most important data on the ionospheric layers (E, F1 and F2 layers, respectively at heights of around 100,180 and $250-350 \mathrm{~km}$ ) are their 'penetration' or 'critical' frequencies $(f \mathrm{E}$, $f \mathrm{~F} 1, f \mathrm{~F} 2$ ) as measured by a sweptfrequency sounder. The series of critical frequency data began at noon on 11 January 1931 (a Sunday, like its fiftieth anniversary) and has continued with few breaks to the present day. Initially only $f \mathrm{E}$ was recorded, on ninety days in 1931 . Tabulated $f \mathrm{~F} 2$ data start on 19 December 1931 , but it was not until 20 September 1932 that the long series of daily values was initiated, the first 'noon run' for which all three parameters $f \mathrm{E}, f \mathrm{~F} 1, f \mathrm{~F} 2$ are preserved being on 23 September 1932. Hourly soundings - which are now made routinely - were made only for three 24-hour periods during 1931; from these data it appears that the initial value at 1200 GMT on 11 January 1931 , namely $2.1 \mathrm{MHz}$, may be about $15-20$ per cent low in comparison with neighbouring

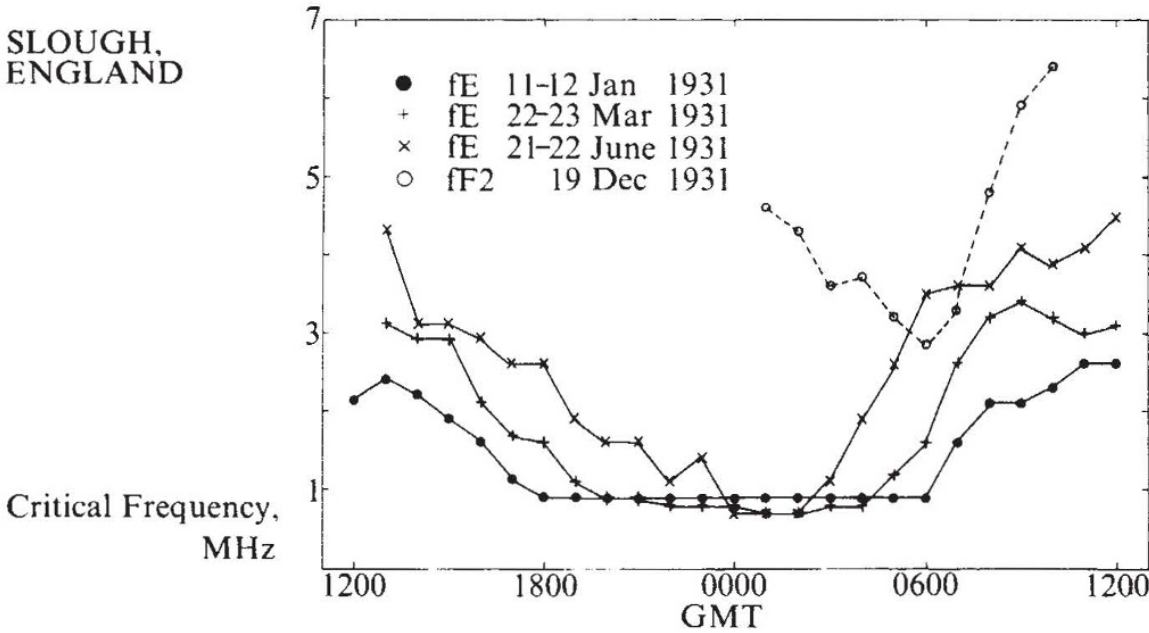

Fig. The four sequences of hourly critical frequency data recorded at Slough $\left(511^{1 / 2}{ }^{\circ} \mathrm{N}, 1 / 2^{\circ} \mathrm{W}\right)$ during 1931

The values refer to the 'ordinary' magnetoionic component. Some of the fluctuations in $\mathrm{fE}$ are probably due to sporadic E. values. Furthermore, it was then also possible to record $f \mathrm{E}$ at night to values as low as $0.7 \mathrm{MHz}$ : this could not be done nowadays with normal ionosondes in England, owing to the prevalence of radio broadcast interference ( $R$. W. Smith, personal communication). Today, data from the Slough ionosonde are distributed to numerous users on schedules to meet their particular needs, which may include long-term 'predictions' of ionospheric conditions or short-term 'forecasts' of disturbances. Some users, including the BBC, Marconi's and Jodrell Bank, receive noon 'critical frequency' data by telex each working day. It is interesting that the largest value of $f F 2$ ever recorded at Slough occurred in the present solar cycle, namely $17.2 \mathrm{MHz}$ at 1300 and 1400 GMT on 15 December 1979.

Other long series of ionospheric data have been produced at Huancayo (Peru), Watheroo (Western Australia) and Washington (DC). By the start of the International Geophysical Year of 1957--58 about 140 ionospheric observatories were in operation, many of which have continued to this day, thereby creating global data sequences extending over two sunspot cycles. This well organized scientific resource is available to researchers through the World Data Centre at Slough, and corresponding Centres in Boulder (Colorado), Moscow and Tokyo, established at the start of the IGY.

What of the future? Following the merger with the SRC Rutherford Laboratory, Appleton Laboratory work is being transferred away from Slough. Current thinking is that an ionosonde should remain permanently in the Slough area. Possibilities being considered for the future are the automatic read-out of data to the merged laboratories' site at Chilton, with dial-up access by users both to past data and to the up-to-the-hour state of 'the part of the atmosphere vertically above Slough'.

Henry Rishbeth is at the Rutherford and Appleton Laboratories, Slough, UK. 